\title{
Acute anorexigenic action of leptin in rainbow trout is mediated by the hypothalamic Pi3k pathway
}

Ningping Gong, Elisabeth Jönsson and Björn Thrandur Björnsson

Fish Endocrinology Laboratory, Department of Biological and Environmental Sciences, University of Gothenburg, Gothenburg, Sweden
Correspondence should be addressed to B T Björnsson Email thrandur.bjornsson@bioenv. gu.se

\begin{abstract}
Leptin (Lep) is an anorexigenic hormone and regulates appetite-related neuropeptides in mammals. A number of neuropeptides have also been linked to appetite regulation in teleost fish, but Lep signaling activation and effects on appetite-regulating neurons are poorly elucidated in early vertebrates. This study uses cellular, tissue and organismal approaches to elucidate the acute, central Lep action in rainbow trout. The results demonstrate that Lep activates phosphorylation of protein kinase B (Akt) and signal transducer and activator of transcription 3 in rainbow trout hypothalamus-derived cells, and that the phosphatidylinositol-3-kinase (Pi3k) inhibitor LY294002 can suppress the Lep-induced Akt phosphorylation. Intracerebroventricular (ICV) Lep administration strongly suppresses food intake at the doses of 0.05 and $0.5 \mu \mathrm{g} \mathrm{Lep} \mathrm{fish-1.} \mathrm{At} \mathrm{low} \mathrm{dose,}$ Lep stimulates hypothalamic transcription of anorexigenic cocaine- and amphetamineregulated transcript (Cart) and orexigenic neuropeptide Y. At high dose, Lep stimulates hypothalamic transcription of anorexigenic proopiomelanocortin (Pomc) A1, A2, and B, while coinjection with LY294002 reverses this upregulation. The data suggest that the anorexigenic action of Lep in rainbow trout is mediated through stimulation of the anorexigenic neuropeptides Pomc and Cart. Furthermore, ICV Lep treatment increases phosphor-Akt-immunoreactive cells in the nucleus lateralis tuberis, periventricular zone along infundibulum, and lateral recess surrounded by nucleus anterior tuberis, while LY294002 inhibits this effect. Lep receptor-immunoreactive cells are also predominant in these regions. These results demonstrate that Lep activates the Pi3k-Akt pathway in the lateral tuberal hypothalamus of rainbow trout for acute appetite regulation, indicating the conservation of anorexigenic Lep action in the mediobasal hypothalamus.
\end{abstract}

$\begin{array}{ll} & \text { Key Words } \\ \text { - leptin } \\ \text { - Pi3k-Akt } \\ \text { - neuropeptide } \\ \text { - } \text { appetite } \\ \text { - teleost fish }\end{array}$

Journal of Molecular Endocrinology (2016) 56, 227-238

\section{Introduction}

Leptin (Lep) is a non-glycosylated $16 \mathrm{kDa}$ peptide hormone, which is conserved through vertebrate evolution (Friedman-Einat et al. 2014, Londraville et al. 2014). It has been identified in many teleost species, including rainbow trout (Oncorhynchus mykiss), showing low protein sequence identity (13-25\%) between fish and human
Leps (Murashita et al. 2008, Gorissen \& Flik 2014). Based on lep gene expression data, the liver appears to be the primary Lep production site in teleosts (Londraville et al. 2014), while mammalian LEP is primarily produced by the adipose tissue (Zhang et al. 1994). LEP has both peripheral and central actions in mammals (Unger 2000, Sandoval \&

Published by Bioscientifica Ltd 
Davis 2003). Data on leptin receptor (LepR) distribution in rainbow trout indicate a similar scope of action in teleosts (Gong et al. 2013, Gong \& Björnsson 2014).

LEP is anorexigenic in mammals, and this central action of LEP on appetite and energy balance is mediated through the dorsomedial, ventromedial, ventral premamillary and arcuate nuclei (ARC) of the mediobasal hypothalamus, where the full-length functional LEP receptor (LEPRb) is highly expressed (Elmquist et al. 1998, Morton et al. 2003). In the ARC, LEP inhibits the gene expression of the orexigenic neuropeptide Y (NPY) and agouti-related peptide (AGRP), and stimulates the expression of the anorexigenic proopiomelanocortin (POMC) and cocaine- and amphetamine-regulated transcript (CART) (Kristensen et al. 1998, Bates et al. 2003, Morrison et al. 2005). The piscine structure homologous to mammalian ARC is the nucleus lateralis tuberis (NLT) within the tuberal hypothalamic region (Berman et al. 2009, Biran et al. 2012). The lateral tuberal hypothalamus is involved in neuroendocrine regulation of the pituitary gland, particularly within the more caudally located NLT region, the periventricular zone along the infundibulum (INF), and lateral recess that is surrounded by the nucleus anterior tuberis (NAT) located rostral to the infundibulum (Meek \& Nieuwenhuys 1998).

A number of neuropeptides, known in mammals to be orexigenic or anorexigenic, have been identified as also having similar roles in appetite control of teleost fish. Npy, Agrp, and orexin are major orexigenic peptides expressed in the central nervous system, whereas Pomc, Cart, cholecystokinin (Cck), and corticotropin-releasing factor (Crf) are anorexigenic factors (Jensen et al. 2001, Leder \& Silverstein 2006, Xu \& Volkoff 2007, Murashita et al. 2009). The presence of Npy, beta-endorphin, and adrenocorticotropic hormone has been demonstrated in the lateral tuberal hypothalamic region in various fish species (Meek \& Nieuwenhuys 1998, Matsuda etal. 2009). In rainbow trout, $n p y$ expression is high in the telencephalon, preoptic area and optic tectum, and relatively lower in the mediobasal hypothalamus (Doyon et al. 2003). While the Pomc genes (pomca1, pomca2, pomcb) are highly expressed in the rainbow trout hypothalamus (Leder \& Silverstein 2006), and the Pomc cell bodies are found in the NLT region (Suzuki et al. 1997, Tollemer et al. 1999). Peripheral Lep treatment of rainbow trout has transiently reduced the hypothalamic npy expression levels, while stimulating the expression of pomca1 and pomca2 (Murashita et al. 2008), indicating a similar neuropeptide mediation of anorexigenic effects of Lep in fish as in mammals. Intracerebroventricular (ICV) administration of Lep into rainbow trout has induced changes related to glucosensing in the hypothalamus and hindbrain to produce anorexia (Aguilar et al. 2010). However, direct Lep action in appetite-related neurons has not been well elucidated in fish.

As a cytokine receptor, LEPRb in mammals has no intrinsic kinase activity and uses the associated Janus kinases (JAKs) for LEP signaling. JAK2 activation allows LEPRb signaling via the signal transducers and activators of transcription (STAT), SHP2-mitogen-activated protein kinase, phosphatidylinositol-3-kinase (PI3K)-protein kinase B (AKT), AMP-activated protein kinase, and the mammalian target of rapamycin (mTOR) pathways (Wauman \& Tavernier 2011). Different LEP-responsive neurons activate and utilize differential signaling pathways, depending on physiological and nutritional states of the organism (Sahu 2011). In NPY/AGRP neurons, LEP activation of STAT3 pathway is insufficient to inhibit NPY/AGRP expression and also requires PI3K pathway (Morrison et al. 2005). In POMC neurons, LEP activates the STAT3 pathway in the regulation of energy homeostasis (Bates et al. 2003) and the PI3K signaling in acute suppression of feeding (Hill et al. 2008).

In rainbow trout, Lep signals target cells primarily through a long-form LepR $\left(\operatorname{LepR}_{\mathrm{L}}\right.$ ) (Gong \& Björnsson 2014), analogous to the mammalian LEPRb receptor. The current understanding of Lep intracellular signaling pathways and effects in nonmammalian vertebrates is limited. The classic LepR-Stat3 signal pathway is evolutionarily conserved in teleosts and frogs (Gong \& Björnsson 2014, Cui et al. 2014). The central action of Lep on glucosensing system can be related to the Jak-Stat and Pi3k-mTor pathway in rainbow trout (Aguilar et al. 2010). The Pi3k inhibitor wortmannin can reverse the effects of human LEP on decreasing $n p y$ transcription in rainbow trout hypothalamic slice cultures (Aguilar et al. 2011).

The aim of this study was to advance knowledge on hypothalamic Lep signaling activation and its effects on appetite regulation in early vertebrates using rainbow trout as a model species. In order to ensure the physiological relevance of the study, recombinant rainbow trout Lep (rtLep) with proven bioactivity (Gong et al. 2013, Gong \& Björnsson 2014) was produced and used. First, Lep signaling pathways were studied in vitro using rainbow trout hypothalamus-derived cell culture. Secondly, ICV injection of rtLep with or without a coinjection of Pi3k inhibitor LY294002 was used to study acute Lep effects at the level of the hypothalamus. Food intake was quantified after ICV administration, after which the gene expression of hypothalamic appetite-regulatory neuropeptides was

Published by Bioscientifica Ltd 
determined by qPCR. Thirdly, immunohistochemistry revealed the distribution of the LepR, as well as Lep signaling activation, in the lateral tuberal hypothalamus.

\section{Materials and methods}

Rainbow trout hypothalamus-derived cell culture: Establishment, cell characterization, and Lep stimulation

Cell culture establishment For the primary cell culture, four juvenile rainbow trouts (body weight (BW) ca 30g) were anesthetized with $0.04 \%$ (v/v) 2-phenoxyethanol and decapitated. The brains were excised under aseptic conditions and the hypothalamus without saccus vasculosus was collected for culture. The collected tissue was washed with Hank's balance salt solution (HBSS) supplemented with $2 \times$ antibiotic and antimycotics (penicillin, streptomycin, and amphotericin; Invitrogen) for $15 \mathrm{~min}$. Then, the tissue was washed with HBSS five times, mechanically dispersed by repeated pipetting using sterile glass pipettes, and exposed to $0.025 \%(\mathrm{w} / \mathrm{v})$ trypsin for $5 \mathrm{~min}$. The enzyme dissociation was deactivated by adding the same volume of complete culture medium, containing Leibovitz's L15 (L15) medium (Sigma-Aldrich) supplemented with 10\% $(\mathrm{v} / \mathrm{v})$ fetal bovine serum (FBS, Sigma-Aldrich, Taufkirchen, Germany), $1 \times$ antibiotic and antimycotics, $4 \mathrm{mmol} \mathrm{L}^{-1}$ glucose, and $15 \mathrm{mmol} \mathrm{L}^{-1}$ HEPES. The dissociated cells were collected by centrifugation at $800 \mathrm{~g}$ for $5 \mathrm{~min}$. The pelleted cells were resuspended in $5 \mathrm{~mL}$ of complete culture medium, plated in a $25 \mathrm{~cm}^{2}$ flask, and incubated at $19^{\circ} \mathrm{C}$. The cells started to attach to the substrate on days 1-2. Unattached cells and tissue debris were discarded through changing the culture medium on days 5-6. Subsequently, culture medium was changed every two weeks and cells became confluent in 1-2 months. The confluent cells were passaged and split 1:2. During the first three passages, the subcultured cells reached confluence in 6-8 weeks, but grew faster after the fourth passage and became confluent in 4 weeks. The hypothalamus-derived cells were named RTHy and used after six passages for cell characterization and Lep stimulation.

RTHy cell characterization After six passages, the RTHy cells were allowed to reach confluence in a $35 \mathrm{~mm}$ petri dish, and then washed once with cold HBSS and lysed in $1 \mathrm{~mL}$ TRIzol (Invitrogen). Total RNA was extracted from the cell lysis using standard TRIzol total RNA extraction protocol. The cDNA was synthesized from the total RNA by SuperScript III first-strand synthesis system (Invitrogen). RT-PCRs were set up using RT-PCR reagents (Sigma-Aldrich), cDNA, and the primers (Table 1) for npy, pomca1, crf, leprl, socs3 (suppressor of cytokine signaling 3), and cfos1.

Lep stimulation of the RTHy cells The RTHy cells from four $75 \mathrm{~cm}^{2}$ flasks were detached from the substrate by $0.25 \%(\mathrm{w} / \mathrm{v})$ trypsin (Invitrogen), split into $35 \mathrm{~mm}$ petri dishes with the density of $3 \times 10^{5}$ cells per dish, and cultured in the complete culture medium for 6 days at $19^{\circ} \mathrm{C}$. Then, the culture medium was changed to basic medium (L15 medium, $4 \mathrm{mmol} \mathrm{L}^{-1}$ glucose, and $15 \mathrm{mmol}$ $\mathrm{L}^{-1}$ HEPES) without FBS, and the cells were serum-starved overnight. The Pi3k inhibitor LY294002 in DMSO stock solution (Merck Chemicals, Nottingham, UK) was diluted to $25 \mu \mathrm{mol} \mathrm{L}-1$ in the basic medium and the cells were pretreated for $15 \mathrm{~min}$ before rtLep treatment. rtLep stock solution was diluted to $0.4,2$, and $10 \mathrm{nmol} \mathrm{L}^{-1}$ in the basic medium and the RTHy cells were treated for 30-60 min. The Lep treatment doses and times were selected based on a previous study on Lep effects on the Jak2-Stat3 pathway in rainbow trout hepatoma cells (Gong \& Björnsson, 2014).

Table 1 Sequences of the primers used for RT-PCR and qPCR

The sequences of primers (F: forwards; R: reverse)

F: ctcgtctggacctttatatgc; R: gttcatcatatctggactgtg F: tctgctcattgctttcttacc; R: agtcggatgtagtattcctctc

F: gcaacaactccgacatctc; R: tatctctatcccccatccc

F: gtggagaaaaacacgaggg; R: tggacatagtggaggagaaag

F: tcgtcaagacggagatggag; R: ttggctgtactgtagagaggc

F: ctcgctgtcaagacctcaactct; R: agttgggttggagatggacctc

F: ccgaaaatcccggcgaaga; R: ttcccatacctctgccttgtg

F: tccccgtcaaggtgcatct; R: tcagtgcccagctctggtct

F: ccagaacctcactgtgacgg; R: cctgctgcctcctctactgc

F: actcgcaggatgaggacaag; R: cggtttggagaaggggatga

F: tcttgaagcctacgccact; R: ggagtctccgtcttcttctgc

F: gaaccatggagagctccagg; R: gcgcactgctctccaacgt

F: atgacgcagccactggaatc; R: tgaccotggagtagctgat

F: caaggatatccgtcgtggca; R: acagcgaaacgaccaagagg
Application for the genes (GenBank accession number/reference)

RT-PCR for npy (AF203902.1)

RT-PCR for crh (AF296672.1)

RT-PCR for leprl (JX878485)

RT-PCR for socs3 (NM_001146168.1)

RT-PCR for cfos1 (AB111054)

RT/Q-PCR for pomca1 (X69808.1)

Q-PCR for npy (AF203902.1)

Q-PCR for pomca2 (Leder \& Silverstein 2006)

Q-PCR for pomcb (X69809)

Q-PCR for cckl (NM 001124345)

Q-PCR for cckn (NM_001124611)

Q-PCR for cart (references of DQ836925.1 \& NM_001146680)

Q-PCR for orexin (KR080508)

Q-PCR for ef1 $\alpha$ (AF498320.1) http://jme.endocrinology-journals.org DOI: 10.1530/JME-15-0279
C 2016 Society for Endocrinology Printed in Great Britain
Published by Bioscientifica Ltd. 
After treatments, the cells were washed once with cold HBSS and scraped from the petri dishes into $300 \mu \mathrm{L}$ cold lysis buffer (50 mmol L-1 Tris- $\mathrm{HCl}, \mathrm{pH} 7.4,0.5 \%(\mathrm{w} / \mathrm{v})$ sodium chloride, 1\% (v/v) Triton-100, 1\% (v/v) IGEPAL CA-630, phosphatase inhibitor cocktail 2 and protease inhibitor cocktail (Sigma-Aldrich)). The cell lysis was incubated on ice for $30 \mathrm{~min}$ and centrifuged at $12,000 \mathrm{~g}$ for $30 \mathrm{~min}$. The supernatants were collected and stored at $-20^{\circ} \mathrm{C}$ for immunoblotting.

\section{Immunoblotting}

The supernatants of RTHy cell extracts in SDS-PAGE loading buffer were heated at $95^{\circ} \mathrm{C}$ for $6 \mathrm{~min}$. The prepared samples were separated in SDS-PAGE gel, with $10 \mu \mathrm{L}$ of loading for the analysis of $\alpha$-tubulin and $20 \mu \mathrm{L}$ for the analysis of Stat3, pStat3, and pAkt. The separated proteins were transferred onto a PVDF membrane (Bio-Rad), and blocked in 5\% (w/v) skimmed milk, 50 mmol L ${ }^{-1}$ Tris-HCl, pH 7.4, and 0.05\% (v/v) Tween-20 (TBST) for $2 \mathrm{~h}$. The antibodies against $\alpha$-tubulin (1:2000 dilution; T9026, Sigma-Aldrich), Stat3, phosphorStat3 (Tyr705) and phospho-Akt1/2/3 (Ser473) (1:200 dilution; sc-7179, sc-7993 and sc-7985, Santa Cruz Biotechnology) were diluted in 3\% (w/v) BSA, TBST, and incubated with the PVDF membranes overnight at $4^{\circ} \mathrm{C}$. The membranes were washed with TBST for $6 \times 5 \mathrm{~min}$, and then incubated with anti-mouse/rabbit IgG horseradish peroxidase-linked antibody (1:33,000 dilution; GE Healthcare) and diluted in 3\% BSA, TBST for $1 \mathrm{~h}$. Then the membranes were washed with TBST for $6 \times 10 \mathrm{~min}$. The antibody-bound protein bands were detected by ECL plus western-blotting detection system and imaged on high performance chemiluminescence film (GE Healthcare).

\section{Fish and intracerebroventricular (ICV) injections}

Juvenile rainbow trout (70-100g BW) were transported from a local hatchery (Antens Laxodling AB, Alingsås, Sweden) to the recirculating aquarium facilities at the Department of Biological and Environmental Sciences, University of Gothenburg. The fish were acclimated to an ad libitum feeding regime in recirculating aerated freshwater at $11^{\circ} \mathrm{C}$ for three weeks prior to the experiments. Fish were hand-fed 3\% BW day ${ }^{-1}$ during the acclimation period and were observed to feed actively. The experiments were approved by the Ethical Committee for Animal Research in Gothenburg (license 85-2012) and comply with current Swedish legislation.
The ICV injections followed an established protocol which has a 90\% success rate for delivery to the third ventricle (Jönsson et al. 2003, 2010). Evaluation of the treatment protocol has demonstrated that ICV injections of physiological saline or LY294002 alone have no significant effects on food intake, compared with untreated fish (data not shown). This is in agreement with previous studies showing no difference in plasma cortisol levels, swimming activity, and food intake between centrally injected fish and untreated controls (Jönsson et al. 2010). Injection of saline without/with Lep had no effect on the crf expression (data not shown). Taken together, these results suggest that the treatment protocol used per se did not induce a measureable stress response or an effect on food intake.

Four experimental groups were created, with fish receiving injection of $1 \mu \mathrm{L}$ of physiological saline alone (C group) or containing $0.05 \mu \mathrm{g}$ rtLep (LoLep group), $0.5 \mu$ g rtLep (HiLep group), or $0.5 \mu \mathrm{g}$ rtLep with 1 nmol LY294002 (HiLep + LY group). The fish, twenty per treatment group, were fasted for $24 \mathrm{~h}$. Fish was netted from the holding tanks, anesthetized in $0.04 \%$ 2-phenoxyethanol, weighed and placed on a wet towel on a PVC board to secure its body position. A free-hand injection was then carried out using a $0.3 \mathrm{~mm}$ microlance needle coupled to a $10 \mu \mathrm{L}$ Hamilton syringe with an $18 \mathrm{P}$ cannula. The needle insertion point is between the two optic tecta in line with the base of the eyes, at a depth of $3 \mathrm{~mm}$ below the skull. After the 5 -min treatment
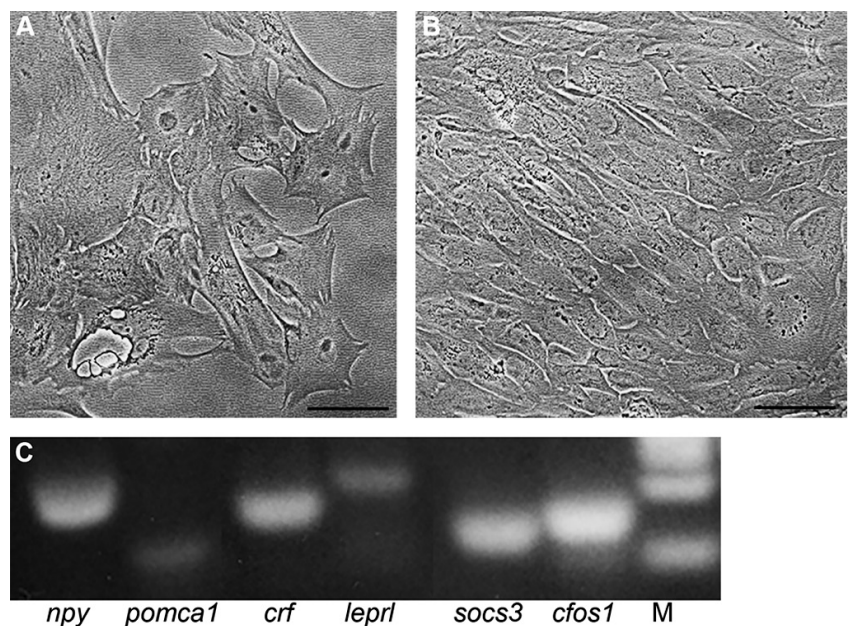

Figure 1

Morphological and RT-PCR characterization of the hypothalamus-derived RTHy cells. The cells after 6 passages have homologous morphology (A) and become fibroblast-like at confluence (B). (C) DNA electrophoresis of the RT-PCR product reveals that the cells express the genes of neuropeptides ( $n p y$, pomca1, and crf), the full-functional LepR $\mathrm{R}_{\mathrm{L}}(/ e p r l)$, socs3, and cfos1. M, DNA ladders. Scale bars, $50 \mu \mathrm{m}$.

Published by Bioscientifica Ltd. 
procedure, each individual was transferred to a separate 50-L glass aquarium with aerated recirculating fresh water at $11^{\circ} \mathrm{C}$, and kept individually for the assessment of food intake. Injected fish normally recovered from anesthesia within $2 \mathrm{~min}$ and were further observed for $10 \mathrm{~min}$ to ensure that they displayed normal behavior, with 90\% success rate. Only fish swimming and behaving normally were included in the experiment.

\section{Food intake quantification and tissue sampling}

Hand-feeding of the fish was initiated $15 \mathrm{~min}$ after the ICV injection $\left(t_{0 \mathrm{~h}}\right)$, and a total amount of $3 \%(\mathrm{w} / \mathrm{w})$ BW

A

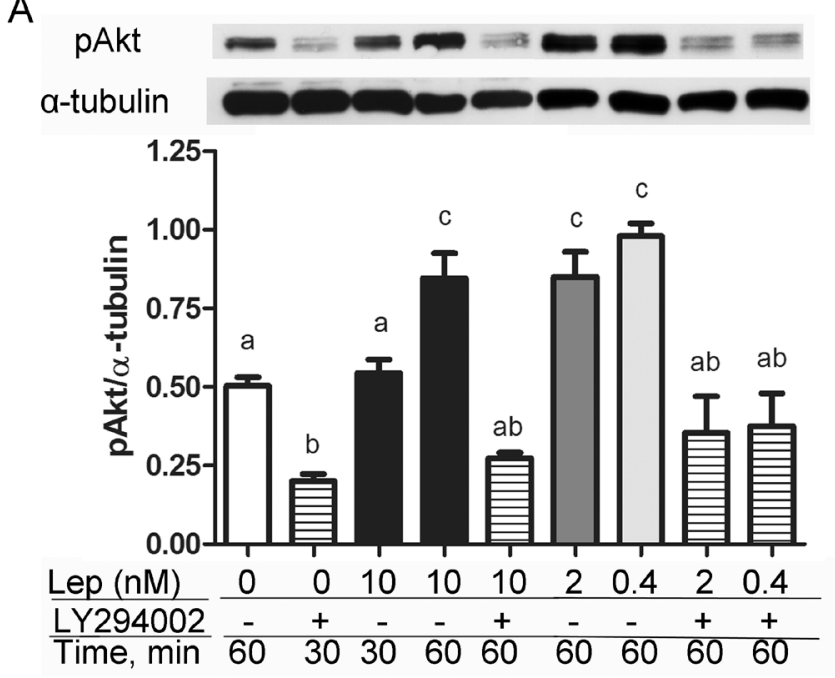

B

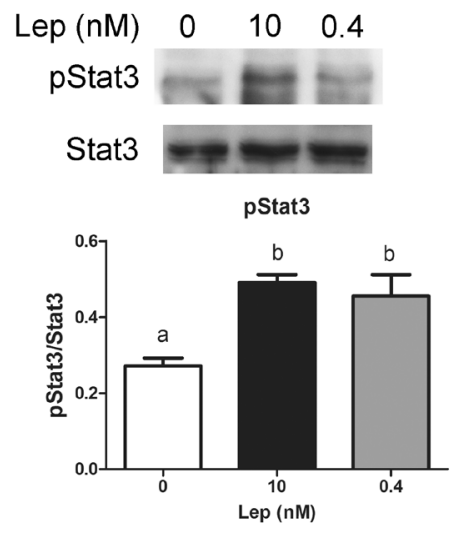

Figure 2

Immunoblotting analysis of phosphorylation levels of Akt (pAkt) and Stat3 (pStat3) in the RTHy cell extracts. A: Lep in $0.4,2$, and $10 \mathrm{nM}$ significantly increases the pAkt levels after $60 \mathrm{~min}$, but not $30 \mathrm{~min}$, whereas the pretreatment of LY294002 reverses the simulation. B: Lep in 0.4 and $10 \mathrm{nM}$ significantly stimulates the pStat3 levels after $60 \mathrm{~min}$. Blank bar, the bars filled in grey or black, and the stripped bars represent the vehicle-treated, Lep-treated and Lep + LY29004 treated groups, respectively. Bars with dissimilar superscripts indicate groups that differ significantly at the level of $P<0.05$. of feed was offered in several batches during one hour $\left(t_{1 \mathrm{~h}}\right)$. The fish were allowed to pick feed from the bottom for an additional $1 \mathrm{~h}$ after which $\left(t_{2 \mathrm{~h}}\right)$ fish were netted for sampling, and remaining feed pellets were collected, dried, and counted to calculate total feed intake in each fish. This is a similar protocol as that has been used previously to assess acute effects of centrally injected hormones on food intake (Jönsson et al. 2003, 2010). The fish were anesthetized in $0.04 \%$ 2-phenoxyethanol and decapitated, after which the hypothalamus was dissected out and preserved in liquid nitrogen for RNA extraction. For immunohistochemistry, three fish (from three individual tanks) were killed $1 \mathrm{~h}\left(t_{1 \mathrm{~h}}\right)$ after injection without feeding, and the brains were taken and preserved in Bouin-Hollande solution for fixation. The Lep doses and the time of tissue sampling (see below) were chosen based on the temporal and quantitative responses observed following the in vitro Lep stimulation of the RTHy cells.

\section{Immunohistochemical (IHC) localization of hypothalamic LepR and pAkt}

The sampled brains were fixed in Bouin-Hollande solution with gentle shaking for 4 days at room temperature. Fixed tissues were dehydrated through a series of ethanol and Histolab Clear solvent, and embedded in paraffin. Serial transverse sections $(8 \mu \mathrm{m})$ were cut by microtome (Shandon Scientific LTD, Cheshire, England) from the rostral to the caudal part and mounted on 3-aminopropyltriethoxysilane-coated

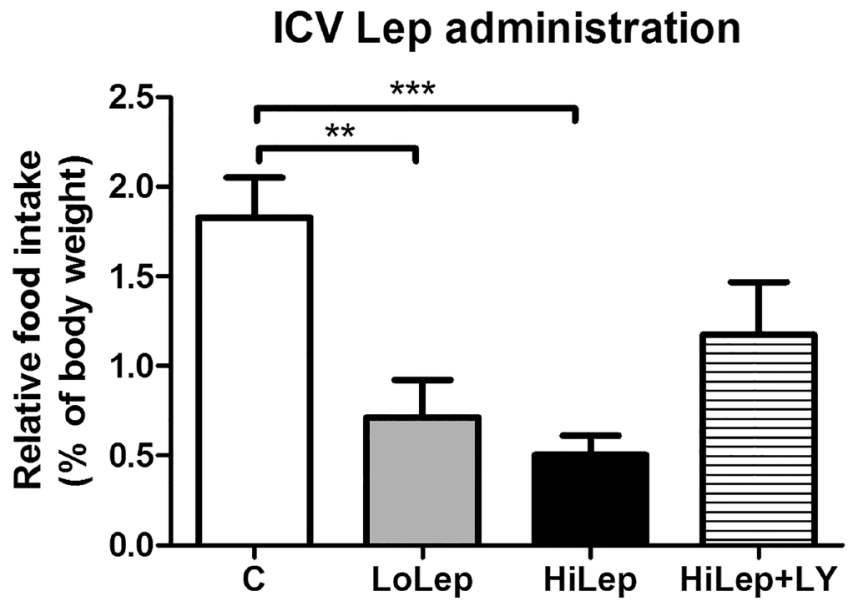

Figure 3

Food intake of rainbow trout in \% BW (mean \pm S.E.M., $n=16) 2 \mathrm{~h}$ after a single central injection of saline solution (C), Lep at low dose $(0.05 \mu \mathrm{g}$; LoLep), at high dose (0.5 $\mu$; HiLep), or high dose with $1 \mathrm{nmol}$ LY294002 (HiLep + LY group). ${ }^{*} P<0.01, * * * P<0.001$.

Published by Bioscientifica Ltd 
A

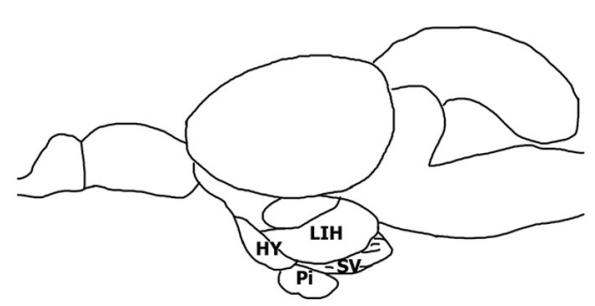

B

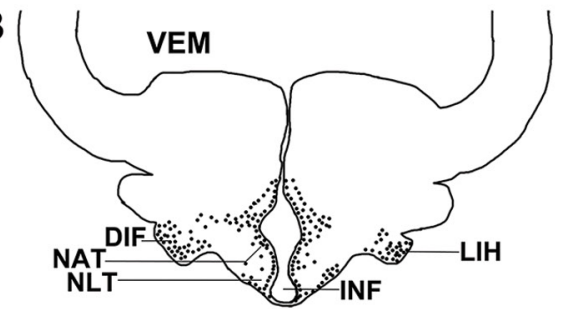

C: Control
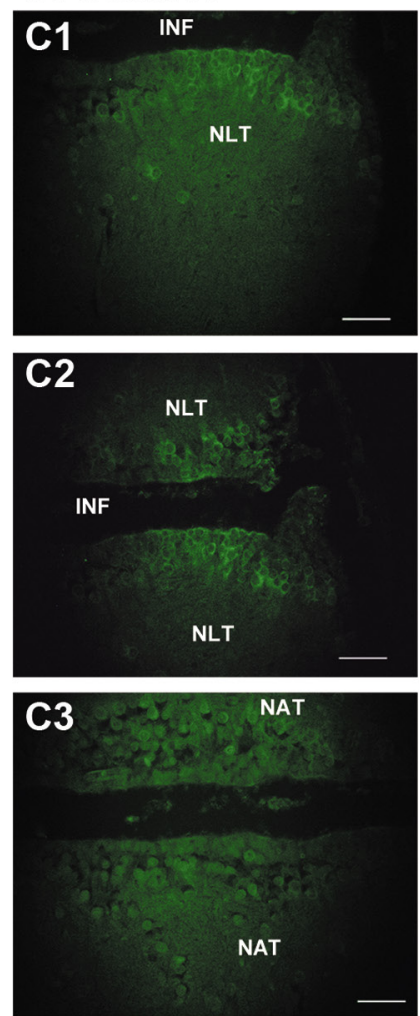

D: HiLep 1\#
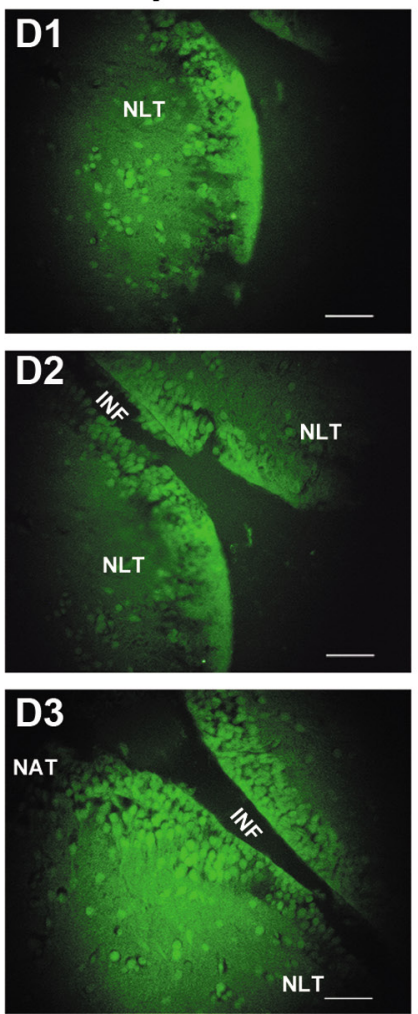

\section{E: HiLep 2\#}
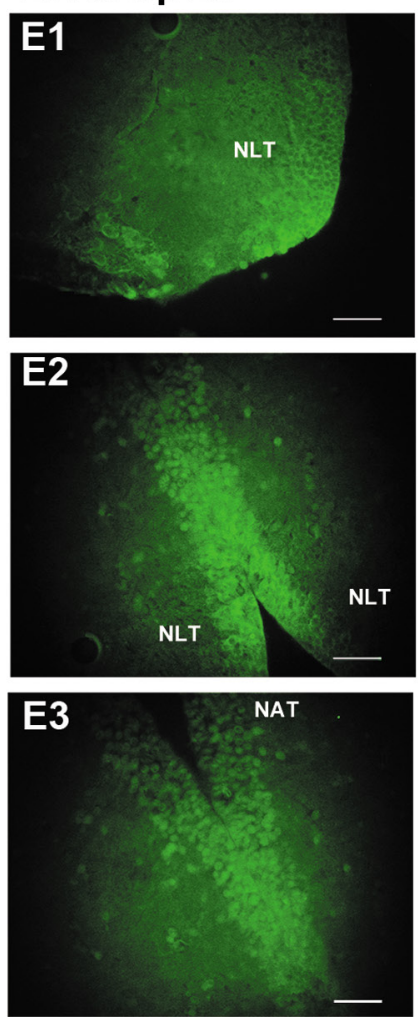

F: HiLep+LY
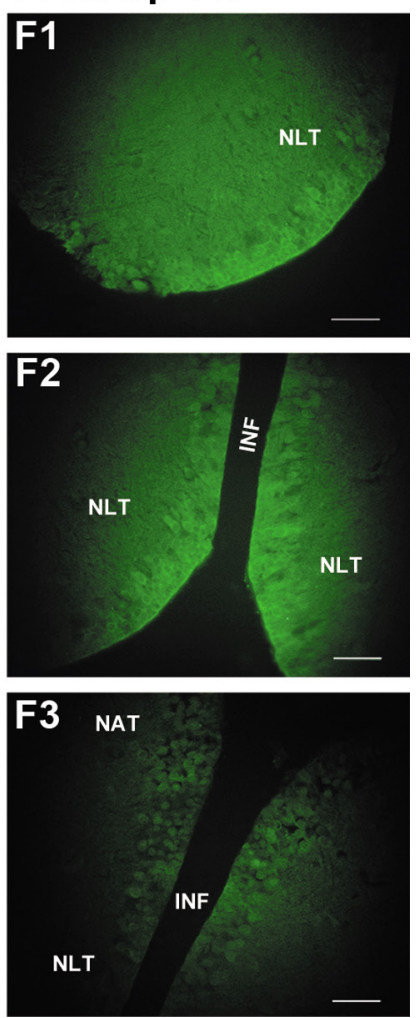

Figure 4

Immunohistochemistry staining phosphorylated Akt (pAkt) in the lateral tuberal hypothalamus. (A) Illustration of brain of the rainbow trout at lateral view; HY, hypothalamus; LIH, lobus inferior hypothalamic; Pi, pituitary; SV, saccus vasculosus. (B) Illustration of the relevant brain cross-section demonstrating the organization of the regions; the drawing modified from the image of transverse section through the brain of rainbow trout (Meek \& Nieuwenhuys 1998); DIF, nucleus diffuses lobi inferioris hypothalamic; INF, infundibulum; NAT, nucleus anterior tuberis; NLT, nucleus lateralis tuberis; VEM, ventriculus mesencephalic. The pAkt-ir neurons stained by FITC (green) are widely distributed in the NLT, the periventricular zone along the INF and the lateral recess of NAT in the brain sections from HiLep-treated fish (D1-3 and E1-3), while the pAkt-ir cells are much less found in the vehicle-treated fish (C1-3) and Lep + LY294002-coinjected fish (HiLep + LY; F1-3). Scale bars, 50 $\mathrm{mm}$. A full colour version of this figure is available at http://dx.doi.org/10.1530/JME-15-0279.

slides. The sections including part of optic tectum, midbrain and hypothalamus were dewaxed, rehydrated, and treated to remove mercury. Then, the slides were washed repeatedly in TBST and made ready for immunostaining. The brain sections were blocked in TBST, 3\% BSA, and 5\% (v/v) normal goat serum for $2 \mathrm{~h}$ at room temperature, followed by application of $150 \mu \mathrm{L}$ primary antibody to LepR (Rabbit anti-rainbow trout LepR antibody, produced with the antigen, recombinant amino acids 703-802 of the rainbow trout LepR $\mathrm{L}_{\mathrm{L}}$; Gong et al. 2013), and phospho-Akt1/2/3 (Ser473) (1:100 dilution) in TBST at $4^{\circ} \mathrm{C}$ overnight. Adjacent sections were used for IHC of phosphor-Akt and LepR. The next day, the sections were washed with TBST and incubated with goat anti-rabbit IgG-FITC antibody or donkey anti-rabbit IgG-Cy3 (1:400 dilution; Sigma-Aldrich) in TBST for $1 \mathrm{~h}$ at room temperature in the darkness. The slides were washed

Published by Bioscientifica Ltd 
A: Control
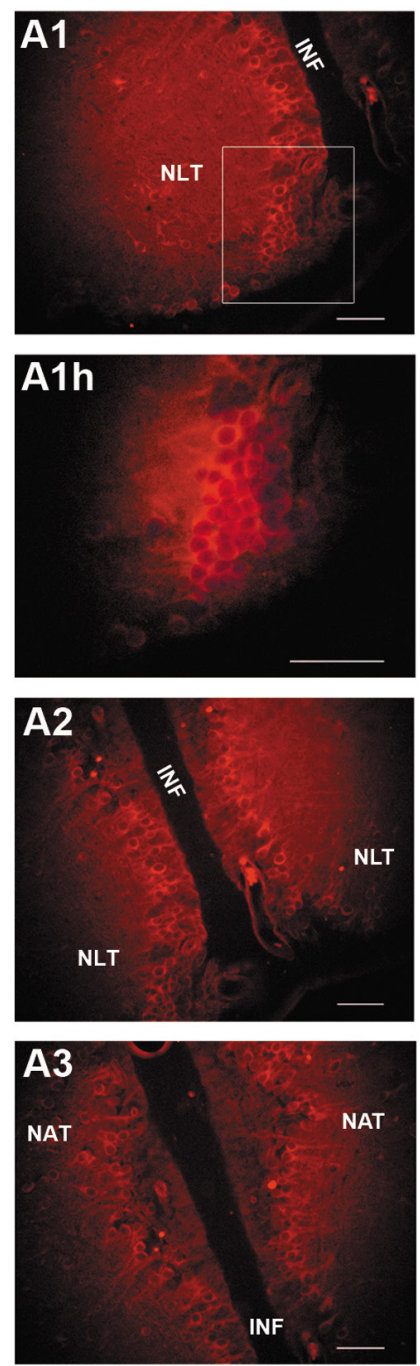

\section{B: HiLep 1\#}
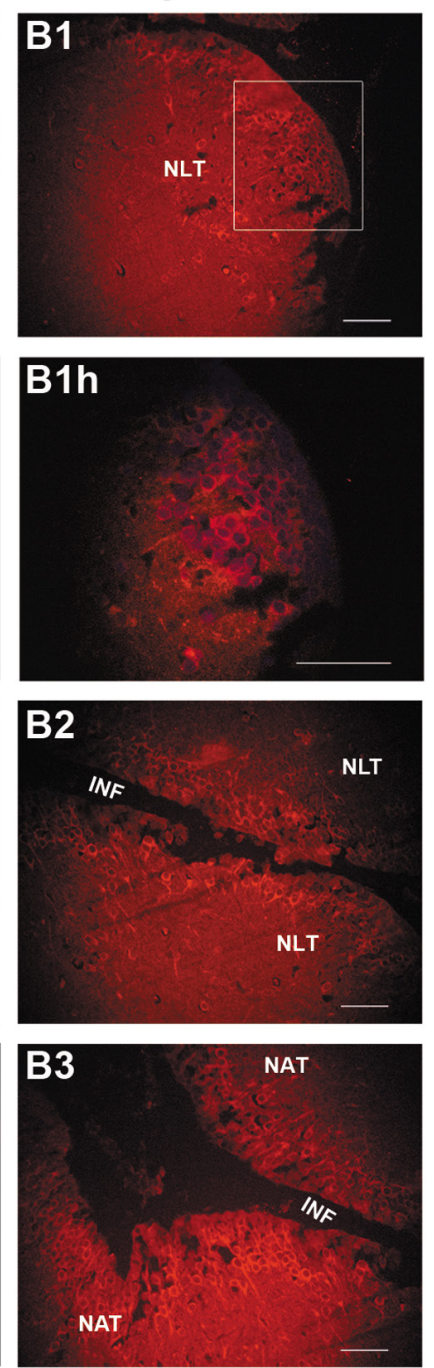

\section{C: HiLep 2\#}
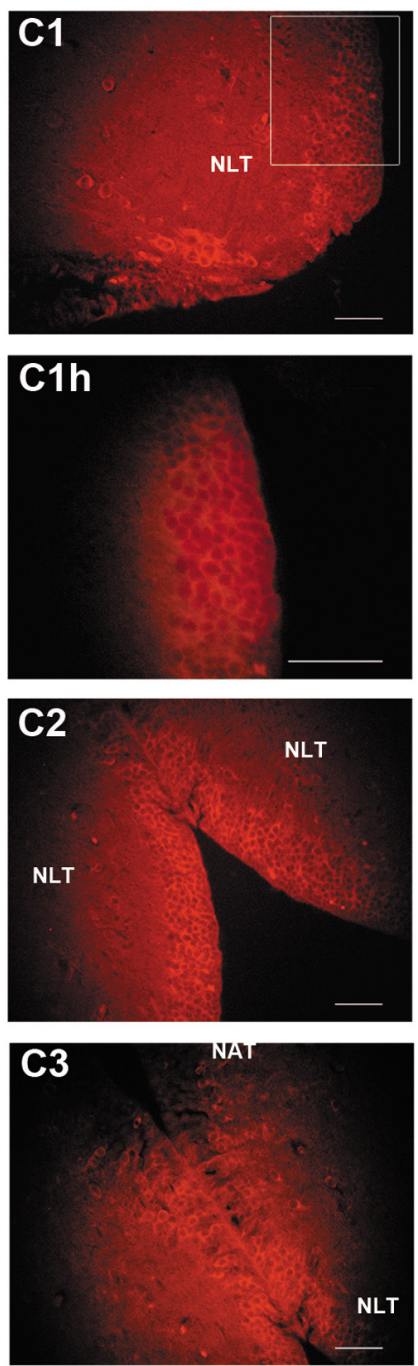

D: HiLep+LY
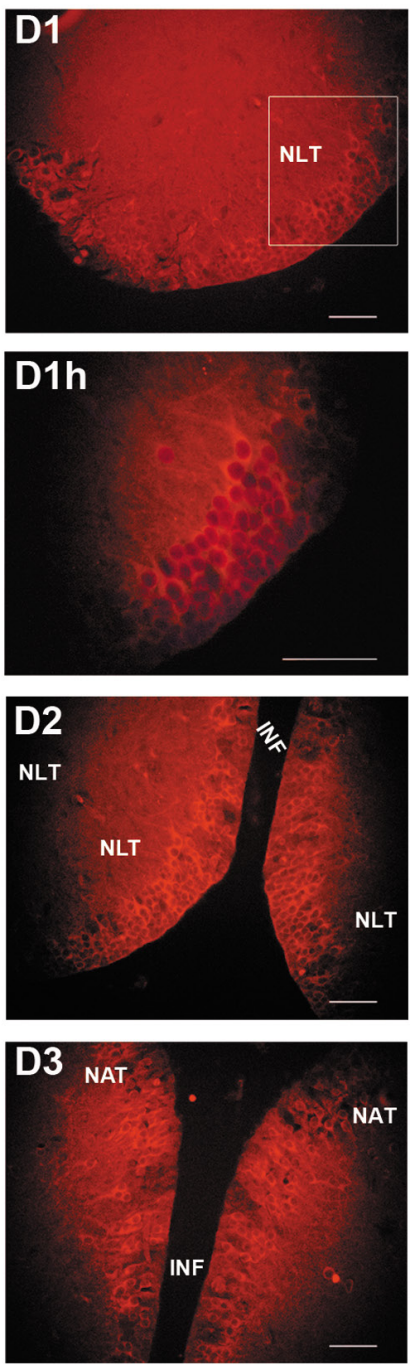

\section{Figure $\mathbf{5}$}

Immunohistochemistry staining of LepR in the lateral tuberal hypothalamus, using brain sections adjacent to those for pAkt IHC, from the vehicletreated (A1-3), Lep-treated (HiLep; B1-3 and C1-3), and Lep + LY294002-treated (HiLep + LY; D1-3) fish. The LepR-ir cells stained by Cy3 (red) have predominant distribution in all brain sections, within the NLT, the periventricular zone along the INF and the NAT regions. Magnifications of the framed areas shown in A1h-D1h reveal that LepR-ir staining (red) are located in the cell membrane, and DAPI stains cell nucleus (blue). Scale bar, 50 m. A full colour version of this figure is available at http://dx.doi.org/10.1530/JME-15-0279.

in TBST and mounted in Vectashield plus DAPI (Vector Laboratories, Burlingame, CA, USA) with a glass coverslip. The fluorescence staining was observed within $48 \mathrm{~h}$ under a fluorescence microscope (Nikon Eclipse E1000) with the appropriate filters for FITC, Cy3, and DAPI. Images were obtained using a digital camera attachment (Nikon DXm1200) and Nikon software ACT1. Negative controls for IHC included omission of the primary or secondary antibodies, and these produced only insignificant staining.

\section{QPCR analysis of hypothalamic gene expression}

The frozen hypothalamus was homogenized in Precellys 24 homogenization automated equipment with the Precellys Kit CK14 (Bertin Technologies, Aix, Tarnos, France). Total RNA was isolated using the RNeasy Mini Kit with efficient removal of genomic DNA (Qiagen). First-strand cDNA was synthesized using iScript cDNA synthesis kit (Bio-Rad Laboratories, Hercules, CA, USA) on $1 \mu \mathrm{g}$ RNA template in $20 \mu \mathrm{L}$ of the final volume. Concurrently, another $1 \mu \mathrm{L}$ RNA with cDNA

Published by Bioscientifica Ltd 
A
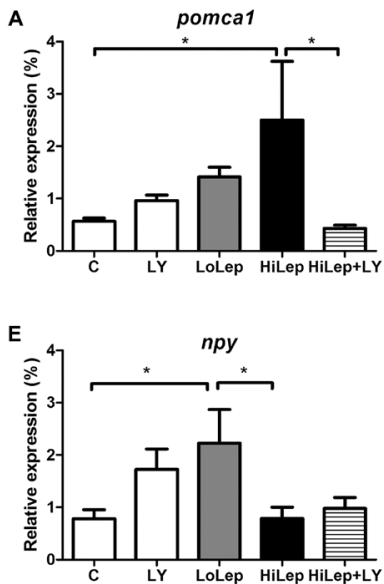

B

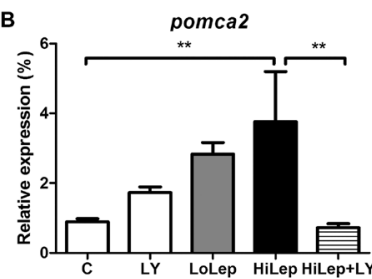

F

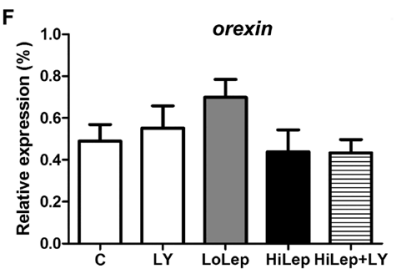

C
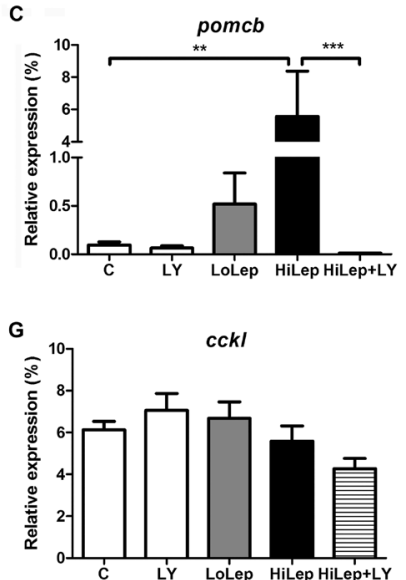

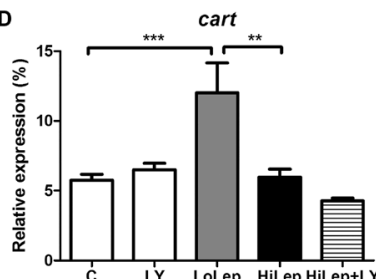

cckn

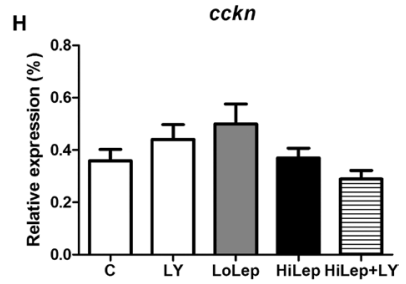

Figure 6

The mRNA transcription of the neuropeptides (PomcA1, PomcA2, PomcB, Cart, Npy, orexin, CckL, and CckN) in the hypothalamus of rainbow trout at $t_{2 \mathrm{~h}}$ injected with the vehicle (C), LY294002 (LY), low Lep dose (LoLep), high Lep dose (HiLep), and high Lep dose with LY294002 (HiLep+LY).

The mRNA expression was normalized by ef1a copy number. Error bars represent standard error of the mean ( $n=7)$.,$* *$, and ***indicate significant differences between treatments at $P<0.05,0.01$ and 0.001 , respectively.

synthesis buffer (without iScript reverse transcriptase) and primers was used as a negative control. The qPCR product amplified from the negative control was $<1 \%$ of the qPCR product from the cDNA sample: $0.2 \mu \mathrm{L}$ cDNA sample was applied for each qPCR analysis of the reference gene, elongation factor EF1 alpha gene (ef1a), while $0.4 \mu \mathrm{L}$ cDNA was applied for the analysis of the target genes (pomca1, pomca2, pomcb, npy, orexin, cart, and $c c k$ variants expressed in the hypothalamus (cckl and cckn; Jensen et al. 2001)). A pooled cDNA sample was diluted in series and applied for standard curve. The qPCR included $300 \mathrm{nmol} \mathrm{L}^{-1}$ primers, cDNA templates, and SSoAdvanced Universal SYBR Green Supermix (Bio-Rad Laboratories) in $10 \mu \mathrm{L}$ of the final volume. The primer sequences are listed in Table 1. Data were collected with Bio-Rad CFX Connect Real-Time System. A melting curve analysis was performed for each qPCR assay and showed a single peak, confirming PCR specificity. The PCR efficiency of the standards was between $95 \%$ and 105\%. The relative expression values of all samples were normalized by ef $1 a$.

\section{Statistical analysis}

Protein bands were quantified by ImageJ software. The food intake, qPCR, and protein band data were analyzed by one-way ANOVA followed by a Turkey's post hoc test to identify differences among treatments. Statistical and correlation analysis of neuropeptide transcription was carried out by GraphPad Prism software, assuming data sampled from Gaussian populations (Pearson), with two-tailed $P$ values.

\section{Results}

\section{Identification of the RTHy cells}

The obtained RTHy cells proliferate slowly and have homologous morphology after 6 passages, attach to substrate for growth, and become fibroblast-like cells at confluence (Fig. 1A and B). The cells have been cryopreserved in L15 medium with 10\% FBS and 5\% (v/v) DMSO and stored in liquid nitrogen. The cells remained viable and proliferative after being thawed and plated in new flasks.

RT-PCR analysis characterized that the RTHy cells showed the expression of the leprl, npy, crf, and Lep-regulated genes (socs 3 and cfos1), and a low expression of pomca1 (Fig. 1C).

\section{Activation of Pi3k-Akt and Stat3 pathways in the RTHy cells}

RtLep treatment significantly increased the phosphorylation of Akt in the RTHy cells after $60 \mathrm{~min}$ (Fig. 2A). Lep significantly activated Akt at the lowest dose $\left(0.4 \mathrm{nmol} \mathrm{L}^{-1}\right)$ tested, and no further activation occurred at higher $\left(2\right.$ and $\left.10 \mathrm{nmol} \mathrm{L}^{-1}\right)$ doses (Fig. 2A). LY294002 significantly attenuated Lep-induced phosphorylation of Akt (Fig. 2A). Furthermore, Lep (0.4 and 10nmol L-1) significantly stimulated phosphorylation of Stat3 in the RTHy cells in 60 min (Fig. 2B).

Published by Bioscientifica Ltd. 


\section{ICV Lep administration and food intake}

During the 2-h feeding period following the ICV injection, the C group consumed $1.83 \% \mathrm{BW}$ of food, while the consumption was significantly reduced by $61 \%$ in the LoLep group and by $73 \%$ in the HiLep group (Fig. 3). Over the same period, the food consumption of the HiLep+LY group did not differ significantly from that of the C group (Fig. 3).

\section{Lep effects on Pi3k-Akt pathway in the tuberal hypothalamic region}

Lep administration induced phosphorylation of Akt in cells of the NLT (Fig. 4D1 and E1), the periventricular zone along the INF (Fig. 4D2 and E2), and the lateral recess of NAT (Fig. 4D3 and E3), compared with the control (Fig. 4C1, 2 and 3). Coinjection of Lep and LY294002 suppressed Lep-induced phosphorylation of Akt in these regions (Fig. 4F1, 2 and 3) compared with Lep injection alone.

Figure 5 shows hypothalamic LepR distribution in the brain sections adjacent to those used for phosphor-Akt IHC, indicating the wide distribution within the NLT, the periventricular zone of the INF, and the lateral recess of NAT regions, in the $\mathrm{C}$ group (Fig. 5A1, 2 and 3), the Lep groups (Fig. 5B1, 2 and 3; C1, 2 and 3), and the Lep $+\mathrm{LY}$ groups (Fig. 5D1, 2 and 3). Magnification of the framed areas in Fig. 5A1, B1, C1 and D1 indicates that the LepR is located in the cell membrane, and the cell nucleus is stained by DAPI (Fig. 5A1h-D1h).

\section{Lep effects on gene expression of hypothalamic neuropeptides}

As shown in Figs. 6A,B,C, the hypothalamic mRNA levels of pomca1, pomca2, and pomcb were significantly increased by the high Lep dose, and this effect was completely blocked by LY294002.

Transcription of cart and npy was significantly increased by the low Lep dose, but not the high Lep dose (Fig. 6D and E). The levels of orexin, $c c k l$, and $c c k n$ transcripts were not significantly affected by Lep treatment (Fig. 6F and H).

The hypothalamic expression of npy correlated positively with those of orexin, cart, and $c c k n$. Also, the cart expression correlated positively with orexin, $c c k n$, and $c c k l$. The three pomc genes correlated positively with each other, and pomca 1 and pomca 2 also correlated positively with $c c k l$ (Fig. 7).

\section{Discussion}

This study demonstrates, through complementary cellular, tissue and organismal approaches, that Lep acutely inhibits food intake and stimulates anorexigenic neuropeptides Pomc and Cart, but does not affect the gene expression of the orexigenic neuropeptides Npy and orexin. Furthermore, the study reveals that the Lep signaling is mediated through the intracellular Pi3k-Akt and Stat3 pathways. Acute Lep administration activates the Pi3k-Akt pathway in the lateral tuberal hypothalamus, where the LepR are highly expressed.

\begin{tabular}{|c|c|c|c|c|c|c|c|c|}
\hline $\begin{array}{l}\mathrm{R}^{2} \text { value } \\
P \text { value }\end{array}$ & npy & & & & & & & \\
\hline orexin & $\begin{array}{l}0.259 \\
0.0035 \\
* *\end{array}$ & orexin & & & & & & \\
\hline cckn & $\begin{array}{l}0.28 \\
0.0003 \\
* \star *\end{array}$ & $\begin{array}{l}0.396 \\
<0.0001 \\
* * *\end{array}$ & cckn & & & & & \\
\hline cckl & $\begin{array}{l}0.0017 \\
0.79 \\
\mathrm{~ns}\end{array}$ & $\begin{array}{l}0.266 \\
0.0011 \\
\star *\end{array}$ & $\begin{array}{l}0.22 \\
0.0017 \\
* *\end{array}$ & cckl & & & & \\
\hline cart & $\begin{array}{l}0.26 \\
0.0005 \\
* \star *\end{array}$ & $\begin{array}{l}0.331 \\
0.0002 \\
* * *\end{array}$ & $\begin{array}{l}0.64 \\
<0.0001 \\
* * *\end{array}$ & $\begin{array}{l}0.26 \\
0.0005 \\
* * *\end{array}$ & cart & & & \\
\hline pomca1 & $\begin{array}{l}0.002 \\
0.77 \\
\mathrm{~ns}\end{array}$ & $\begin{array}{l}0.026 \\
0.337 \\
\mathrm{~ns}\end{array}$ & $\begin{array}{l}0.044 \\
0.18 \\
\mathrm{~ns}\end{array}$ & $\begin{array}{l}0.11 \\
0.031 \\
*\end{array}$ & $\begin{array}{l}0.021 \\
0.36 \\
\mathrm{~ns}\end{array}$ & pomca1 & & \\
\hline pomca2 & $\begin{array}{l}0.013 \\
0.47 \\
\text { ns }\end{array}$ & $\begin{array}{l}0.06 \\
0.145 \\
\text { ns }\end{array}$ & $\begin{array}{l}0.11 \\
0.03 \\
*\end{array}$ & $\begin{array}{l}0.16 \\
0.007 \\
* *\end{array}$ & $\begin{array}{l}0.064 \\
0.1 \\
\text { ns }\end{array}$ & $\begin{array}{l}0.85 \\
<0.0001 \\
\star * *\end{array}$ & ротса2 & \\
\hline pomcb & $\begin{array}{l}0.00002 \\
0.97 \\
\text { ns }\end{array}$ & $\begin{array}{l}0.0009 \\
0.955 \\
\mathrm{~ns}\end{array}$ & $\begin{array}{l}0.021 \\
0.36 \\
\mathrm{~ns}\end{array}$ & $\begin{array}{l}0.05 \\
0.17 \\
\mathrm{~ns}\end{array}$ & $\begin{array}{l}0.0001 \\
0.8 \\
\mathrm{~ns}\end{array}$ & $\begin{array}{l}0.77 \\
<0.0001 \\
* * *\end{array}$ & $\begin{array}{l}0.81 \\
<0.0001 \\
* \star *\end{array}$ & pomcb \\
\hline
\end{tabular}

http://jme.endocrinology-journals.org DOI: 10.1530/JME-15-0279
C 2016 Society for Endocrinology Printed in Great Britain

\section{Figure 7}

Correlations among the gene expression of hypothalamic neuropeptides. 
The recent demonstration (Gong \& Björnsson 2014) of relatively high expression of the leprl gene in the rainbow trout hypothalamus has prompted the establishment of the RTHy cell culture to be used in the current study for the elucidation of Lep signaling pathways. The validity of this approach, as demonstrated in this study, hinged on the ability of the RTHy cells to express the LepR $_{\mathrm{L}}$ and hypothalamic neuropeptides, providing evidence for their hypothalamic origin and maintained some functional properties. The potent Lep stimulation of Akt phosphorylation in the RTHy cells, and the reversal of this by the Pi3k inhibitor LY294002, provides clear evidence for Lep activating the Pi3k-Akt pathway in the rainbow trout hypothalamic cells. Lep also stimulates Stat3 phosphorylation in the RTHy cells, as previously demonstrated in the rainbow trout hepatoma cell line RTH149 (Gong \& Björnsson 2014). As Lep activates the Jak2-Stat3 and Pi3k-Akt pathways also in mammals (Wauman \& Tavernier 2011), the current data show that these intracellular signaling mechanisms for Lep are evolutionarily conserved in vertebrates.

The highest leprl mRNA levels in the rainbow trout brain are found in the hypothalamus (Gong \& Björnsson 2014). The IHC visualization of hypothalamic LepR distribution reveals predominant presence of LepR in the lateral tuberal hypothalamus, especially in the NLT, the periventricular zone of the INF, and the NAT regions. The LepR-immunoreactive (Lep-ir) staining is in the cell membrane, which can be interpreted as showing the localization of the functional LepR $_{\mathrm{L}}$. This is further supported by the increased phosphor-Akt-ir cells in this hypothalamic area following a central Lep injection, as the change in intracellular signaling must be induced through the functional Lep receptor. Thus, the $\operatorname{LepR}_{\mathrm{L}}$ distribution in rainbow trout appears to be similar to that in rat, where the full-length LEPRb is predominantly found within the arcuate, dorsomedial, and ventromedial nuclei (Elmquist et al. 1998), as well as in Xenopus, where the LepR is found within the ventral hypothalamus (Cui et al. 2014).

The Lep-induced stimulation of Akt phosphorylation in the lateral tuberal hypothalamus as well as increase in hypothalamic pomc expression, and blocking of these Lep-induced effects by LY294002, strongly suggest that Lep stimulates pomc expression through the Pi3k-Akt pathway in this brain region. The rainbow trout pomc genes are predominantly expressed in the hypothalamus and pituitary gland (Leder \& Silverstein 2006), and cells bodies containing Pomc are primarily located in the NLT region and pituitary gland (Suzuki et al. 1997,
Tollemer et al. 1999). Although colocalization of Pomc and LepR $_{\mathrm{L}}$ has not been examined in the current study, the presence of LepR $\mathrm{R}_{\mathrm{L}}$ as well as the activation of the Pi3k-Akt pathway by Lep in this region strongly suggests a direct Lep action in Pomc neurons, resulting in the increased expression of the pomca1, pomca2, and pomcb genes by the ICV Lep injection.

The acute anorexigenic effect of ICV-injected Lep supports previous studies indicating a conserved appetite-suppressing function of Lep through the vertebrate series (Londraville et al. 2014). As LY294002 partially reverses this suppression, the importance of the Pi3k signaling pathway for the central action of Lep in the rainbow trout is further confirmed. The present data also agree with studies using peripheral Lep treatment of rainbow trout and Atlantic salmon, indicating that the anorexigenic action of Lep in salmonids is mediated through the Pomc pathway (Murashita et al. 2008, 2011). These data are also in agreement with data on frog Xenopus laevis, where ICV Lep administration increases pomc transcription (Cui et al. 2014). Also in mammals, LEP primarily acts on the POMC/CART neurons in the ARC (Varela \& Horvath 2012), while in fish, the NLT of the hypothalamus is considered to be homologous to the mammalian ARC (Biran et al. 2012). Collectively, these studies support the notion that the role of Lep in regulating Pomc neurons in the mediobasal hypothalamus has been conserved through vertebrate evolution.

In contrast to mammals, where NPY-producing neurons are also targets of LEP action in the ARC, inhibiting fastinginduced Npy expression in rat (Morrison et al. 2005), no suppressive effect of Lep on npy expression was observed in the rainbow trout at $2 \mathrm{~h}$ post-feeding. In fact, $n p y$ expression was elevated by the low Lep dose, while the high dose had no significant effect. Similar response variability has been noted in other studies on early vertebrates. The ICV Lep administration transiently increased npy mRNA levels in frog brain (Cui et al. 2014). In the goldfish Carassius auratus that had been acclimated to a feeding schedule, ICV Lep administration did not affect $n p y$ expression in fed fish at $2 \mathrm{~h}$ post-feeding, but suppressed fasting-induced $n p y$ expression in unfed fish (Volkoff et al. 2003). Peripheral Lep treatment also suppressed npy expression in 24-h fasted rainbow trout (Murashita et al. 2008). In addition, Lep decreased $n p y$ expression in slices from rainbow trout hypothalamus without affecting pomc expression (Aguilar et al. 2011). The effects of Lep on npy expression in rainbow trout hypothalamus slices were dependent on glucose concentration (Aguilar et al. 2011). These disparate $n p y$ responses suggest that Lep effects on $n p y$ expression

Published by Bioscientifica Ltd 
may vary with nutritional status. In rainbow trout, $n p y$ expression is high in the telencephalon, preoptic area, and optic tectum, while relatively lower in the mediobasal hypothalamus (Doyon et al. 2003). The Npy cell bodies in the diencephalon are mainly detected in the nucleus ventromedial thalamus and the ventral nucleus posterioris periventricularis (Matsuda et al. 2009, Pérez et al. 2013), while Npy-containing fibers can be found throughout the brain, including the hypothalamus (Danger et al. 1991). This distribution pattern may be also relevant to the differentiated regulation of Npy by Lep in the mediobasal hypothalamus.

The Lep-induced elevation of cart expression in the rainbow trout is similar to that found in goldfish (Volkoff et al 2003). The concomitant appetite suppression supports the notion of Cart as an anorexigenic neuropeptide in rainbow trout (Gesto et al. 2014), and that the anorexigenic Lep effect in rainbow trout is to some extent mediated through Cart.

The other appetite-related neuropeptides assessed in the current study, orexin and Cck (CckN and CckL), were not significantly affected by the central Lep administration, but on the other hand, a broad correlation was observed between the expression of orexigenic and anorexigenic neuropeptides, e.g. significant correlation of Npy with orexin and Cart. It has been also observed in goldfish that mutual signaling pathways mediate Npy and orexin (Kojima et al. 2009).

This study demonstrates through ICV administration that Lep has a direct, acute anorexigenic effect at the level of hypothalamus in the rainbow trout, by stimulating the anorexigenic neuropeptides Pomc and Cart. Moreover, the study elucidates that Lep targets the lateral tuberal hypothalamic neurons by activating the Pi3k-Akt pathway for acute appetite suppression. Although differences in tissue origination and relation with adiposity have been observed between fish Lep and mammalian LEP (Londraville et al. 2014), the results show similar mechanisms of central Lep signaling at the cellular and intracellular levels, as well as function in acute appetite control in the mediobasal hypothalamus among fish and mammals.

\section{Declaration of interest}

The authors declare that there is no conflict of interest that could be perceived as prejudicing the impartiality of the research reported.

\section{Funding}

This work was supported by grants from the European Community's Seventh Framework Programme (FP7/2007-2013) under grant agreement no 222719, project LIFECYCLE, as well as from the Swedish Research Council for Environment, Agricultural Sciences and Spatial Planning (FORMAS) grant 223-2011-1356 and to EJ from Carl Tryggers Foundation.

\section{References}

Aguilar AJ, Conde-Sieira M, Polakof S, Míguez JM \& Soengas JL 2010 Central leptin treatment modulates brain glucosensing function and peripheral energy metabolism of rainbow trout. Peptides $\mathbf{3 1}$ 1044-1054. (doi:10.1016/j.peptides.2010.02.026)

Aguilar AJ, Conde-Sieira M, López-Patiño MA, Míguez JM \& Soengas JL 2011 In vitro leptin treatment of rainbow trout hypothalamus and hindbrain affects glucosensing and gene expression of neuropeptides involved in food intake regulation. Peptides 32 232-240. (doi:10.1016/j.peptides.2010.11.007)

Bates SH, Stearns WH, Dundon TA, Schubert M, Tso AW, Wang Y, Banks AS, Lavery HJ, Haq AK, Maratos-Flier E, et al. 2003 STAT3 signalling is required for leptin regulation of energy balance but not reproduction. Nature 421 856-859. (doi:10.1038/nature01388)

Berman JR, Skariah G, Maro GS, Mignot E \& Mourrain P 2009 Characterization of two melanin-concentrating hormone genes in zebrafish reveals evolutionary and physiological links with the mammalian MCH system. Journal of Comparative Neurology $\mathbf{5 1 7}$ 695-710. (doi:10.1002/cne.22171)

Biran J, Palevitch O, Ben-Dor S \& Levavi-Sivan B 2012 Neurokinin Bs and neurokinin $\mathrm{B}$ receptors in zebrafish-potential role in controlling fish reproduction. PNAS 109 10269-10274. (doi:10.1073/ pnas.1119165109)

Cui MY, Hu CK, Pelletier C, Dziuba A, Slupski RH, Li C \& Denver RJ 2014 Ancient origins and evolutionary conservation of intracellular and neural signaling pathways engaged by the leptin receptor. Endocrinology 155 4202-4214. (doi:10.1210/en.2014-1301)

Danger JM, Breton B, Vallarino M, Fournier A, Pelletier G \& Vaudry H 1991 Neuropeptide-Y in the trout brain and pituitary: localization, characterization, and action on gonadotropin release. Endocrinology 128 2360-2368. (doi:10.1210/endo-128-5-2360)

Doyon C, Gilmour KM, Trudeau VL \& Moon TW 2003 Corticotropinreleasing factor and neuropeptide Y mRNA levels are elevated in the preoptic area of socially subordinate rainbow trout. General and Comparative Endocrinology 133 260-271. (doi:10.1016/S00166480(03)00195-3)

Elmquist JK, Bjørbaek C, Ahima RS, Flier JS \& Saper CB 1998 Distributions of leptin receptor mRNA isoforms in the rat brain. Journal of Comparative Neurology 395 535-547. (doi:10.1002/ (SICI)1096-9861(19980615)395:4<535::AID-CNE9>3.0.CO;2-2)

Friedman-Einat M, Cogburn LA, Yosefi S, Hen G, Shinder D, Shirak A \& Seroussi E 2014 Discovery and characterization of the first genuine avian leptin gene in the rock dove (Columba livia). Endocrinology 155 3376-3384. (doi:10.1210/en.2014-1273)

Gesto M, Soengas JL, Rodríguez-Illamola A \& Míguez JM 2014 Arginine vasotocin treatment induces a stress response and exerts a potent anorexigenic effect in rainbow trout, Oncorhynchus mykiss. Journal of Neuroendocrinology 26 89-99. (doi:10.1111/jne.12126)

Gong N, Einarsdottir IE, Johansson M \& Björnsson BT 2013 Alternative splice variants of the rainbow trout leptin receptor encode multiple circulating leptin-binding proteins. Endocrinology 154 2331-2340. (doi:10.1210/en.2012-2082)

Gong N \& Björnsson BT 2014 Leptin signaling in the rainbow trout central nervous system is modulated by a truncated leptin receptor isoform. Endocrinology 155 2445-2455. (doi:10.1210/en.2013-2131)

Gorissen M \& Flik G 2014 Leptin in teleostean fish, towards the origins of leptin physiology. Journal of Chemical Neuroanatomy 61-62 200-206. (doi:10.1016/j.jchemneu.2014.06.005)

Published by Bioscientifica Ltd. 
Hill JW, Williams KW, Ye C, Luo J, Balthasar N, Coppari R, Cowley MA, Cantley LC, Lowell BB \& Elmquist JK 2008 Acute effects of leptin require PI3K signaling in hypothalamic proopiomelanocortin neurons in mice. Journal of Clinical Investigation 118 1796-1805. (doi:10.1172/JCI32964)

Jensen H, Rourke IJ, Møller M, Jønson L \& Johnsen AH 2001 Identification and distribution of CCK-related peptides and mRNAs in the rainbow trout, Oncorhynchus mykiss. Biochimica et Biophysica Acta 1517 190-201. (doi:10.1016/S0167-4781(00)00263-3)

Jönsson E, Johansson V, Björnsson BT \& Winberg S 2003 Central nervous system actions of growth hormone on brain monoamine levels and behavior of juvenile rainbow trout. Hormones and Behavior 43 367-374. (doi:10.1016/S0018-506X(03)00010-2)

Jönsson E, Kaiya H \& Björnsson BT 2010 Ghrelin decreases food intake in juvenile rainbow trout (Oncorhynchus mykiss) through the central anorexigenic corticotropin-releasing factor system. General and Comparative Endocrinology 166 39-46. (doi:10.1016/j. ygcen.2009.11.001)

Kojima K, Kamijo M, Kageyama H, Uchiyama M, Shioda S \& Matsuda K 2009 Neuronal relationship between orexin-A- and neuropeptide Y-induced orexigenic actions in goldfish. Neuropeptides 43 63-71. (doi:10.1016/j.npep.2009.01.004)

Kristensen P, Judge ME, Thim L, Ribel U, Christjansen KN, Wulff BS, Clausen JT, Jensen PB, Madsen OD, Vrang N, et al. 1998 Hypothalamic CART is a new anorectic peptide regulated by leptin. Nature 393 72-76. (doi:10.1038/29993)

Leder EH \& Silverstein JT 2006 The pro-opiomelanocortin genes in rainbow trout (Oncorhynchus mykiss): duplications, splice variants, and differential expression. Journal of Endocrinology 188 355-363. (doi:10.1677/joe.1.06283)

Londraville RL, Macotela Y, Duff RJ, Easterling MR, Liu Q \& Crespi EJ 2014 Comparative endocrinology of leptin: assessing function in a phylogenetic context. General and Comparative Endocrinology 203 146-157. (doi:10.1016/j.ygcen.2014.02.002)

Matsuda K, Kojima K, Shimakura S, Miura T, Uchiyama M, Shioda S, Ando H \& Takahashi A 2009 Relationship between melaninconcentrating hormone- and neuropeptide Y-containing neurons in the goldfish hypothalamus. Comparative Biochemistry and Physiology. Part A: Molecular \& Integrative Physiology 153 3-7. (doi:10.1016/j. cbpa.2008.10.002)

Meek J \& Nieuwenhuys R 1998 Holosteans and teleosts. In The Central Nervous System of Vertebrates, pp 896-897. Eds R Nieuwenhuys, HJ Ten Donkelaar \& C Nicholson. Berlin, Germany: Springer.

Morrison CD, Morton GJ, Niswender KD, Gelling RW \& Schwartz MW 2005 Leptin inhibits hypothalamic Npy and Agrp gene expression via a mechanism that requires phosphatidylinositol 3-OH-kinase signaling. American Journal of Physiology. Endocrinology and Metabolism 289 E1051-E1057. (doi:10.1152/ajpendo.00094.2005)

Morton GJ, Niswender KD, Rhodes CJ, Myers MG Jr, Blevins JE, Baskin DG \& Schwartz MW 2003 Arcuate nucleus-specific leptin receptor gene therapy attenuates the obesity phenotype of Koletsky $(\mathrm{fa}(\mathrm{k}) / \mathrm{fa}(\mathrm{k}))$ rats. Endocrinology 144 2016-2024. (doi:10.1210/en.2002-0115)

Murashita K, Uji S, Yamamoto T, Rønnestad I \& Kurokawa T 2008 Production of recombinant leptin and its effects on food intake in rainbow trout (Oncorhynchus mykiss). Comparative Biochemistry and Physiology. Part B: Biochemistry \& Molecular Biology 150 377-384. (doi:10.1016/j.cbpb.2008.04.007)
Murashita K, Kurokawa T, Ebbesson LO, Stefansson SO \& Rønnestad I 2009 Characterization, tissue distribution, and regulation of agoutirelated protein (AgRP), cocaine- and amphetamine-regulated transcript (CART) and neuropeptide Y (NPY) in Atlantic salmon (Salmo salar). Comparative Biochemistry and Physiology. Part A: Molecular \& Integrative Physiology 162 160-171 (doi:10.1016/j. ygcen.2009.03.015)

Murashita K, Jordal AE, Nilsen TO, Stefansson SO, Kurokawa T, Björnsson BT, Moen AG \& Rønnestad I 2011 Leptin reduces Atlantic salmon growth through the central pro-opiomelanocortin pathway. Comparative Biochemistry and Physiology. Part A: Molecular \& Integrative Physiology 158 79-86. (doi:10.1016/j. cbpa.2010.09.001)

Pérez Sirkin DI, Suzuki H, Cánepa MM \& Vissio PG 2013 Orexin and neuropeptide Y: Tissue specific expression and immunoreactivity in the hypothalamus and preoptic area of the cichlid fish Cichlasoma dimerus. Tissue \& Cell 45 452-459. (doi:10.1016/j. tice.2013.09.001)

Sahu A 2011 Intracellular leptin-signaling pathways in hypothalamic neurons: the emerging role of phosphatidylinositol-3 kinasephosphodiesterase-3B-cAMP pathway. Neuroendocrinology 93 201-210. (doi:10.1159/000326785)

Sandoval DA \& Davis SN 2003 Leptin: metabolic control and regulation. Journal of Diabetes and its Complications 17 108-113. (doi:10.1016/ S1056-8727(02)00167-8)

Suzuki M, Bennett P, Levy A \& Baker BI 1997 Expression of MCH and POMC genes in rainbow trout (Oncorhynchus mykiss) during ontogeny and in response to early physiological challenges. General and Comparative Endocrinology 107 341-350. (doi:10.1006/gcen.1997.6936)

Tollemer H, Teitsma CA, Leprince J, Bailhache T, Vandesande F, Kah O, Tonon MC \& Vaudry H 1999 Immunohistochemical localization and biochemical characterization of two novel decapeptides derived from POMC-A in the trout hypothalamus. Cell and Tissue Research 295 409-417. (doi:10.1007/s004410051247)

Unger RH 2000 Leptin physiology: A second look. Regulatory Peptides 92 87-95. (doi:10.1016/S0167-0115(00)00154-3)

Varela L \& Horvath TL 2012 Leptin and insulin pathways in POMC and AgRP neurons that modulate energy balance and glucose homeostasis. EMBO Reports 13 1079-1086. (doi:10.1038/ embor.2012.174)

Volkoff H, Eykelbosh AJ \& Peter RE 2003 Role of leptin in the control of feeding of goldfish Carassius auratus: interactions with cholecystokinin, neuropeptide $\mathrm{Y}$ and orexin A, and modulation by fasting. Brain Research 972 90-109. (doi:10.1016/S00068993(03)02507-1)

Wauman J \& Tavernier J 2011 Leptin receptor signaling: pathways to leptin resistance. Frontiers in Bioscience 16 2771-2793. (doi:10.2741/3885)

Xu M \& Volkoff H 2007 Molecular characterization of prepro-orexin in Atlantic cod (Gadus morhua): Cloning, localization, developmental profile and role in food intake regulation. Molecular and Cellular Endocrinology $27128-37$. (doi:10.1016/j.mce.2007.03.003)

Zhang Y, Proenca R, Maffei M, Barone M, Leopold L \& Friedman JM 1994 Positional cloning of the mouse obese gene and its human homologue. Nature 372 425-432. (doi:10.1038/372425a0)

Received in final form 10 December 2015

Accepted 14 December 2015

Accepted Preprint published online 14 December 2015 http://jme.endocrinology-journals.org

DOI: 10.1530/JME-15-0279
๑) 2016 Society for Endocrinology Printed in Great Britain
Published by Bioscientifica Ltd 